\title{
大気オゾンの年変化と子午線分布に関する理論
}

\author{
三宅 泰 雄*, 猿 橋 勝 子**
}

\section{On the Theory of Annual Variation and Meridional Distributin of Ozone}

\author{
Y. Miyake, K. Saruhashi \\ (Meteorological Research Institute)
}

The mass distribution of atmospheric ozone on the earth was calculated assuming that distributions of ozone on the northern and southern hemispheres are approximately the same only with half a year difference of phase. Results showed that the total mass of ozone is always constant. On the other hand, calculated amount of ozone by our previous theory decreases rapidly with increasing $\sec z$. Therefore, meridional distribution of photochemically formed ozone and that observed are quite different, but the total mass is equal to the latter and it becomes also constant on the whole earth. We considered that initial distributions are decided photochemically and actual distributions are formed secondly by pole-ward transports of ozone in the stratosphere. The speed and direction of the transport and their seasonal variations were estimated by which the annual and meridional variation of ozone could be explained reasonably.

\section{第 1 章 問 題 $\odot$ 所在}

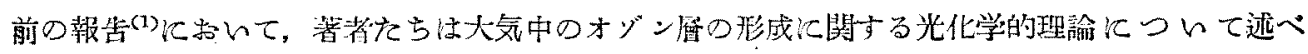

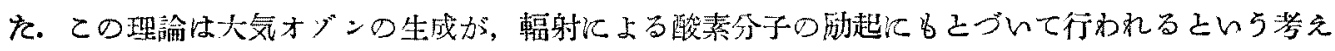

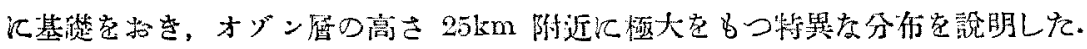

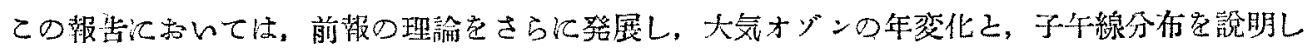

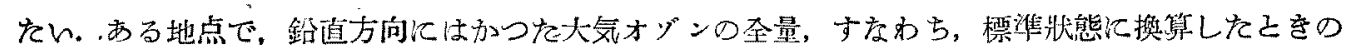

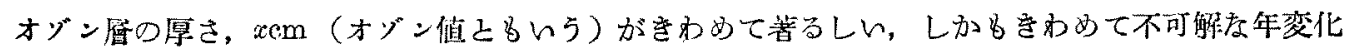

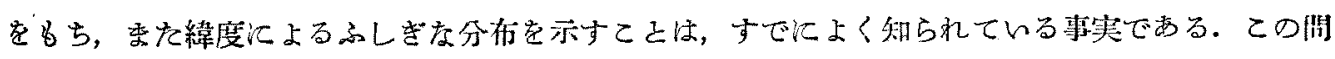

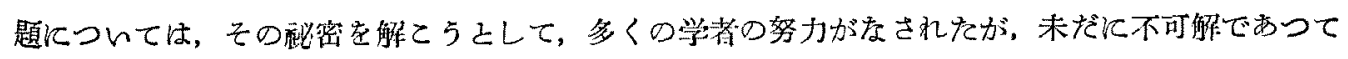

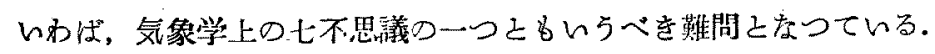

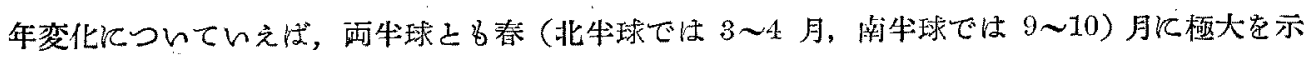
し，秋に極小が現われる，年較差は商緯度在ど大きく，赤道附近では一年中大した変化をしない。

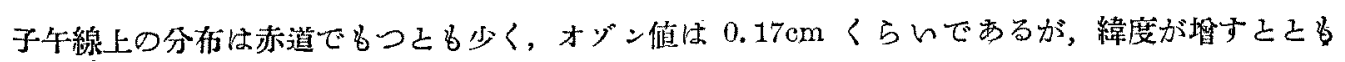
に㴰加し, $55^{\circ} \sim 60^{\circ}$ の間で極大さなり，乙の附近で $x$ は $0.3 \mathrm{~cm}$ 以上Kなる.

\section{*,** 気像研究所}




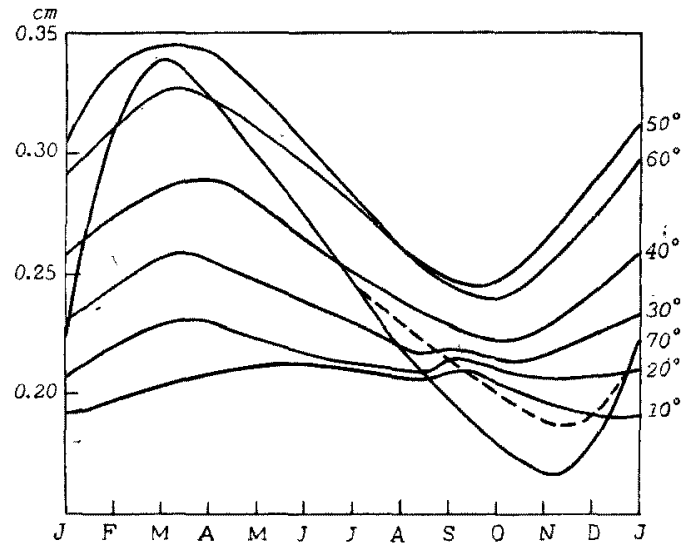

Fig 1. Annual and meridional variation of ozone.

大気オゾンの生成の原因は，前耀でるの゙で 上5に，太陽の紫外軦射に上る光化学反応の 絬果であるから，輻射强度のひとしい春分之 秋分のころに，極大己極小が逆淿あらわれる ことは，理解に苦しせところである. 光化学 本衡にあオオン゙ン量が、輻射强度の大きいは ど增加するて上は，後の計算によつてる分る が，実際のオゾンの分布は輻射强度のもつさ も大きい赤道で小さく，極沂づくに從つて 大となることも常織では理解できない.

この問題に対する從来の学者の考えを一べ つしてみ上5.をとえば, S. Chapman "は オゾンの年変化の週期分析を行つを結果, 春仙はオブンの生成量が秋の 3 倍くらい多いか, あるい

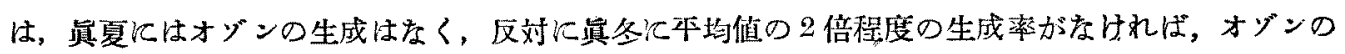

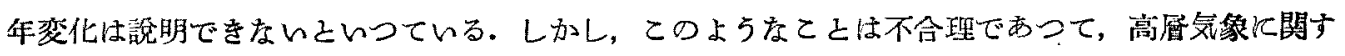
る確奏な資料が入手できないが゙り。この問題の解決は困難であるうとしている。

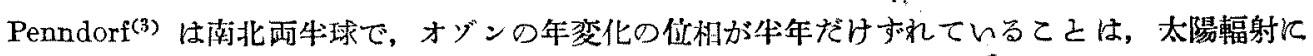

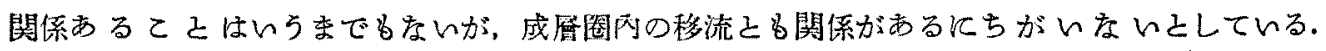
Nicolet ア A. Vassy, E. Vassy ${ }^{(5)}$ は，半化学反応速度にたいする気溫の影響を考え，オゾンの年

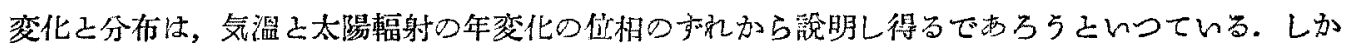
し, これにをんしては，最近，H. U. Dütsch(6) によつて反ぱくされている. Dobson(7) はオダン の年変化亡緯度分布を說明するただ一つの道は，太陽輻射で生じねオゾンが低緯度から高稦度に向 つて大気の槀層队を流れ，極に近づくにしたがい下降すると考えるてとであり，その結果としてオ

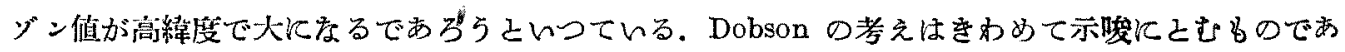

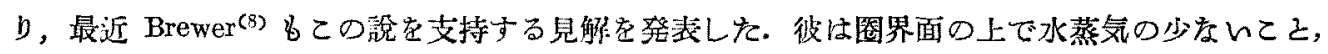
ヘリウム含量が対流图と大差のないて之から見て，成磨圈では擾乱や鉛直混合がないという從来 の考充を訂正すべきであるといつている. Brewer によれば，赤道地方で圈界面からの空気与显 があり，中緯度地方では，方の空気は圈界面に沿らて極の方に流れ，高緯度に近つくにしたがつて

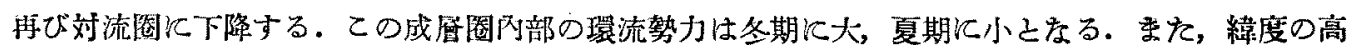

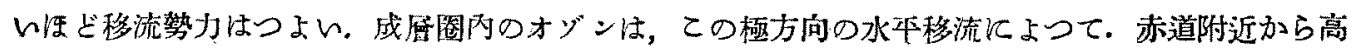
緯度地方にはてばれる，もしそらなら，乙の大環流樊力の年変化之輻射の年变化の位相が重なる結 
果, オゾン值の特異な年变化を生するであるうこん.5.H. U. Dütsch ${ }^{(9)}$ は光化学反応の溫度係数 之輻射の変化だりではオゾンの年変化が說明できないてとを計算によつて示した. 彼は, 夏牛球之

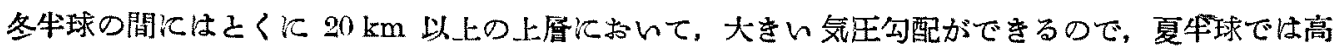
居大気の、上㫒，冬には下降が起ると考えた。 その結果は，子午線方向の環流を生じてれがオゾンの

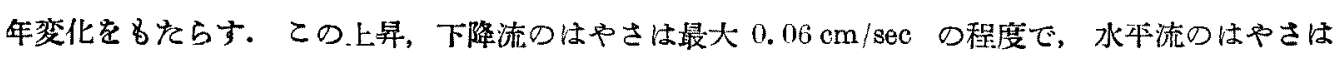
$10^{2} \sim 10^{2} \mathrm{~cm} / \mathrm{sec}$ のオーダーであろうとしている.

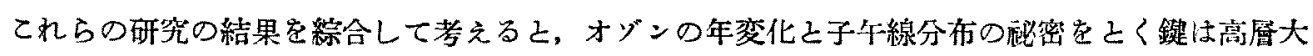
気の運動にかかつているようである。これを逆にんえば，オン゙ンの観測からわれわれはまだ直接に は観測されていない成庴圈內の風系を推察することも可能である5.

ててで注意すべをてとは，オゾン值は，年变化の他に，日日変動を示すことである．ての日日変

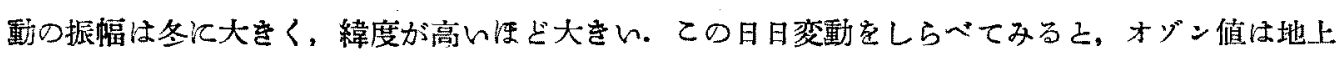

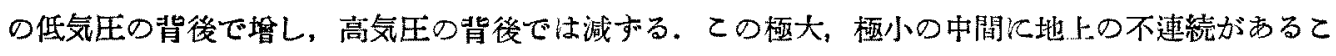

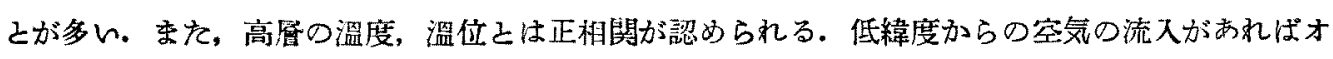
ゾン值は娍じ、高緯度からの流入注よりオン゙ン值は坦加する。

この日ßの変動の原因については, M. Nicolet, ${ }^{(4)}$ Moser, ${ }^{(10)}$ Dütsch, ${ }^{(9)}$ Reel $^{(11)}$ 等の研究により,

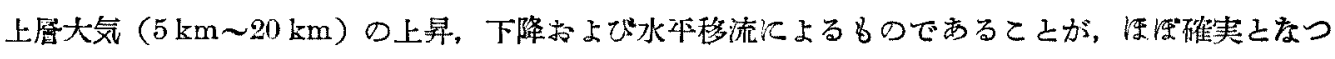

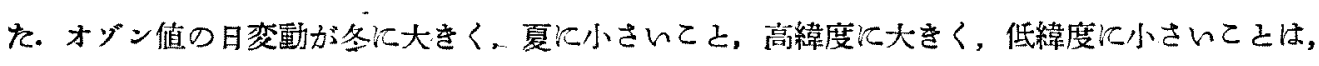
てれが大気の擾乱の度合の季郎变化に比例しているてとは明らかである。

このオブンの日日変動は, 直接て红年変化之関係はないが, 日日変動の季䬣之地域に上る振幅の 相違はオゾンの年変化の問題と密接関連しているらしく思われる.

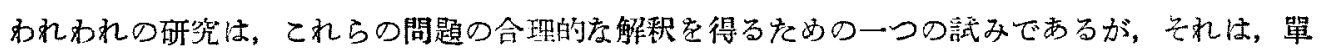
にォゾンの年変化と子午線分布を說明するばかりでなく, 高曆大気, とくに $20 \mathrm{~km}$ から $30 \mathrm{~km}$ らいの唇の運動にたんして一つの示唆を手えるであらう。

\section{第 2 章 地球上におけるオン゙ンの質量分布と全オン゙ン量つ一定性}

レままで，大気オゾンの年变化や，子午線分布を考察する之きは，多くの煬合一つの牛球だけに

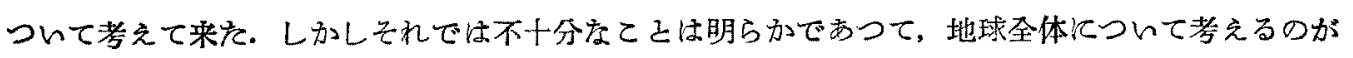
合理的である.

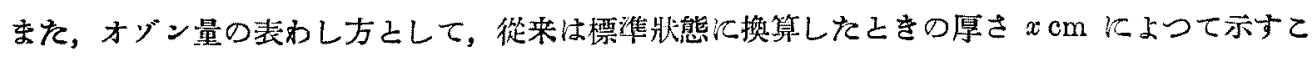
こが慣習となつている，ての表現法は，ある一地点上のオブン量の特間的变化，あるいは，二つの 地点上のオゾン量の多少を比較するには，よい表わし方であるが，ある面積上にあるオゾンの質量 (M) を問題にするときには，不十分な表現法である。 
いま，オゾン值 $x$ が，緯度線上で注一定で，子午線方向にのみある分布をるつとする。この之

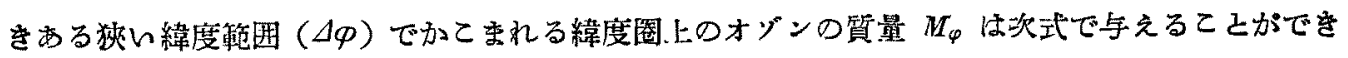
万.

$$
M_{\varphi}=\frac{2 m}{V} \cdot x_{\varphi} \cdot \pi \cdot R^{2} \cdot \cos \varphi \cdot \Delta \phi
$$

こてに $R$ は地球の牛径， $m$ はオゾンの分子量、 $V$ は標準状態における1モルのオゾンの容積 cc である.

地球上のオゾン值 $x$ の分布は，为1図に見るように，高緯度に近づくにしたがつて，相当に大 をい傾ををるつて增加しているが，てててで注目すべきてとは，緯度が高くなるとともに，單位経度

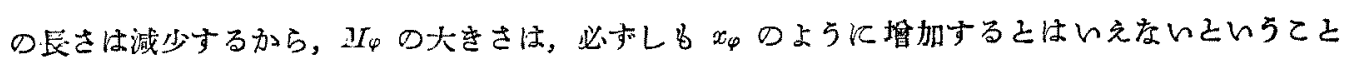
である

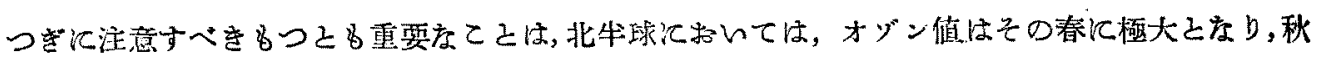

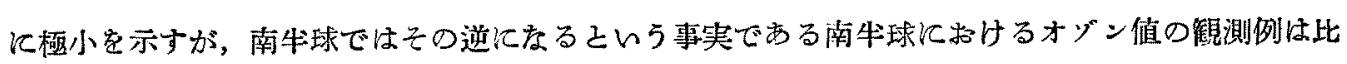

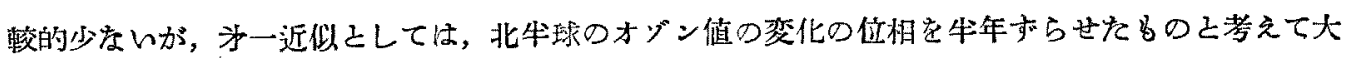

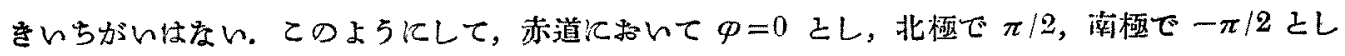
て，全地球上のオグン質量の子年線上の分布を月別て求めてみるよ，为2图の点線のよ5になる。
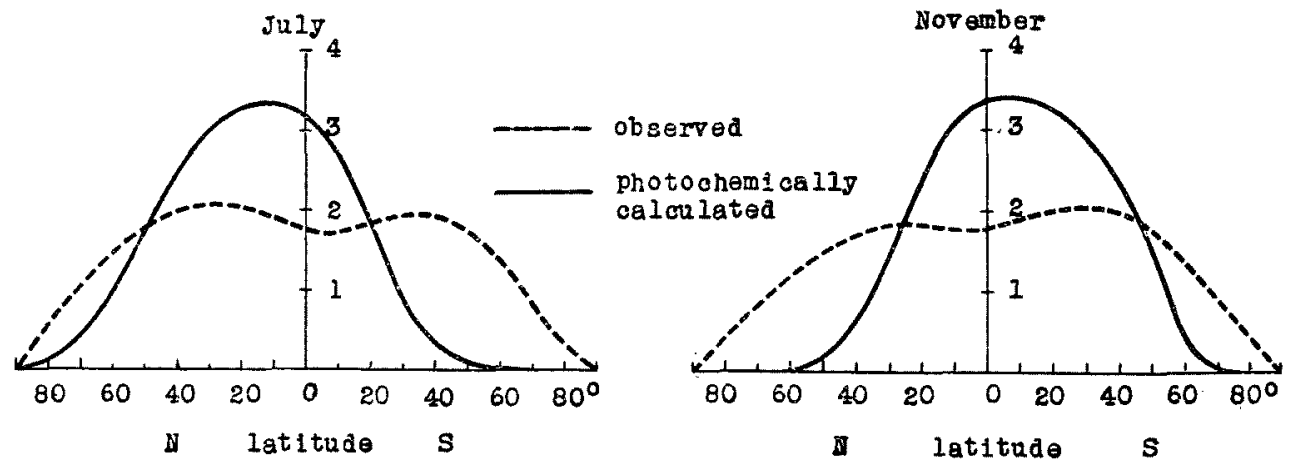

Fig. 2 Meridional mass distribution of ozone.

ての図で明らかなようK，オゾン質量が一つの牛球で少なくなれば，他の牛球では䝬し，またそ の逆になる.したがつて地球上のオン゙ン質量の総和は一年中はこんどひとしくなるてとが期待され る. 実際にオゾン質量の総和 $M$ (total) は次式によつて計算することができる.

$$
M_{\text {total }}=\frac{2 m \pi R^{2}}{V} \int_{-\pi / 2}^{\pi / 2} x \cdot \cos \varphi \cdot d \varphi
$$

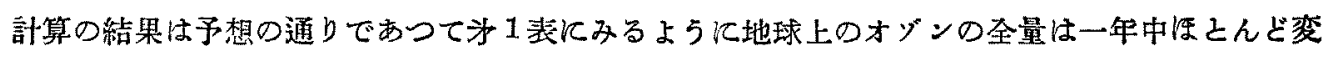
化しないことが分る。地球上の雨牛球ではそれぞれ，んちじるしいオゾン值の年変化を示すが，オ 


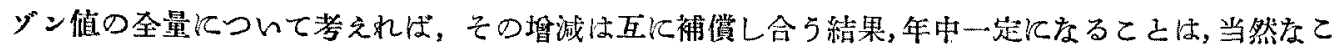

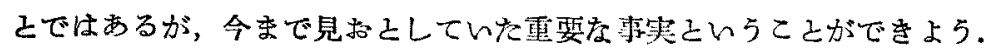

Table 1. The total amount of ozone on the earth and its annual variation

\begin{tabular}{l|c|c|c|c|c|c}
\hline & \multicolumn{2}{|c|}{ N-Hemisphere } & \multicolumn{2}{|c|}{ S-Hemisphere } & \multicolumn{2}{|c}{ Total } \\
\cline { 2 - 6 } & obs. & calc. & obs. & oalc. & obs. & cale. \\
\hline Jan. & 1.26 & 0.70 & 1.36 & 1.64 & 2.62 & 2.34 \\
Feb. & 1.35 & 0.85 & 1.20 & 1.62 & 2.52 & 2.47 \\
Mar. & 1.40 & 1.11 & 1.16 & 1.50 & 2.56 & 2.61 \\
Apr. & 1.39 & 1.36 & 1.19 & 1.24 & 2.58 & 2.60 \\
May. & 1.35 & 1.65 & 1.17 & 0.94 & 2.52 & 2.59 \\
June. & 1.27 & 1.72 & 1.19 & 0.71 & 2.47 & 2.43 \\
July. & 1.36 & 1.64 & 1.26 & 0.70 & 2.62 & 2.34 \\
Aug. & 1.20 & 1.62 & 1.35 & 0.85 & 2.52 & 2.47 \\
Sep. & 1.16 & 1.50 & 1.40 & 1.11 & 2.56 & 2.61 \\
Oct. & 1.19 & 1.24 & 1.39 & 1.36 & 2.58 & 2.60 \\
Nov. & 1.17 & 0.94 & 1.35 & 1.65 & 2.52 & 2.59 \\
Dec. & 1.19 & 0.71 & 1.27 & 1.72 & 2.47 & 2.43 \\
\hline
\end{tabular}

(unit: $10^{\mathrm{s}}$ ton)

\section{第 3 章 オン゙ンの光化学的平衙量の分布と年变化について}

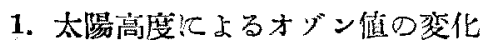

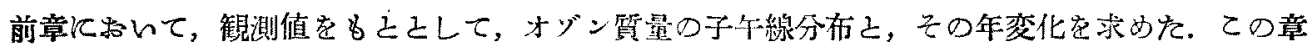

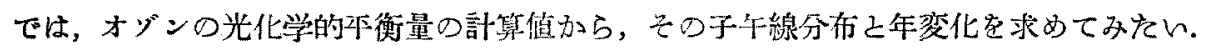

著者をちは(1)，さきに大気オブンの形成に関する光化学的理論を的したが,ての理論においては, 炏の上ら度光化学反応を，オゾンの光化学的平衡の基濋さした。

生成

$$
\begin{aligned}
& O_{2}+h \nu=O_{2}{ }^{\prime \prime}\left({ }^{3} \Sigma^{-\mu}\right) \\
& O_{2}+O_{2}^{\prime \prime}+M=O_{3}+O^{\prime}\left({ }^{1} D\right)+M \\
& O_{2}+O^{\prime}+M=O_{3}+M
\end{aligned}
$$

分解

$$
\begin{aligned}
& O_{3}+h \nu=O_{2}{ }^{\prime}\left({ }^{1} \Sigma\right)+O^{\prime}\left({ }^{1} D\right) \\
& O_{3}+O+M=2 O_{2}+M
\end{aligned}
$$

前報における計算はすへて，太陵は天頂にあるもの之した場合で，太陽高度の変化につんては考

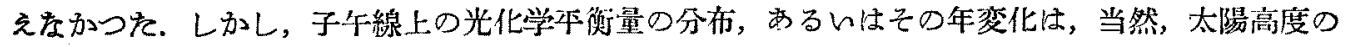
差異に上る輻射量の变化に件5るので㐫るから，日射の路程を考慮に入れる必亚が西る。

われわれの導いた光化学本衡の基本式は Mecke ${ }^{(2)}$ のbの同じ形であるが, Mecke の理諭亡異 るさころは，太陽輻射の波瑗分布之，オゾン及び酸素の光吸收係数の波長分布它考慮に入れたて之 である。 それは次式叱よつて表わされる。

$$
\left[O_{3}\right]^{2} /\left[O_{2}\right]^{2}=K \cdot p \cdot \alpha q / \beta q^{\prime}
$$

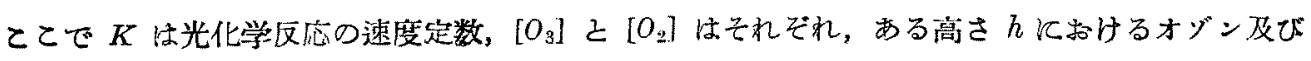


酸素の分汪， $p$ はその高さの気王， $\alpha ， \beta$ はそれでれ西る波长儿おける酸素及びオソンの光吸收係 数， $q ， q^{\prime}$ はそれぞれその波长に和いて酸秦分子を殿起し，オゾンを分解するのに有効な光量子数

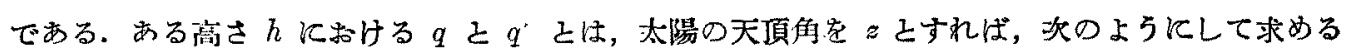
ことができる。

$$
\begin{gathered}
q_{\lambda}=q_{0 \lambda} e-\int_{n}^{\infty} \alpha_{\lambda} \sec z[O]_{2} d h \\
q^{\prime} \lambda^{\prime}=q_{0 \lambda^{\prime}} \cdot e-\int_{n}^{\infty} \beta_{\lambda^{\prime}} \sec z\left[O_{3}\right] d h
\end{gathered}
$$

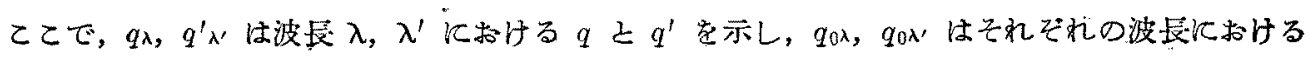
大気外の光量子数， $\alpha \lambda ， \beta_{\lambda^{\prime}}$ はそれぞれ $\lambda ， \lambda^{\prime}$ に数ける $\alpha, \beta$ 表內す.

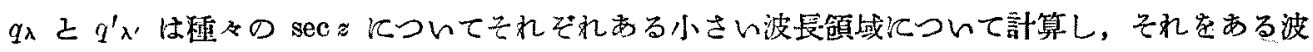

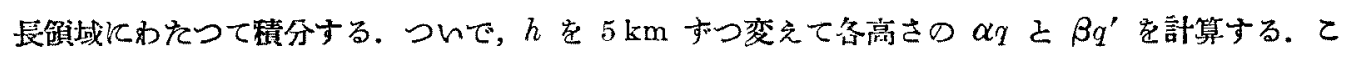
のようにして各高さのオゾンの分王を炏式加ら求める.

$$
\left[O_{3}\right]=K^{1 / 2}\left[O_{2}\right]^{3 / 2} \cdot p^{1 / 2} \cdot(\alpha q)^{1 / 2} \cdot\left(\beta q^{\prime}\right)^{-1 / 2}
$$

つぎててを地上から大気外なで皘分し，

$$
x=\int_{0}^{\infty}\left[O_{3}\right] d h
$$

によつて，太陽高度を異にする場合のオゾン值 れを求めるここができる。

$K$ の值は，オグンの生成反応 (4)，(5) 及び分解反店 (て)の活性化エホルギーが不明なので, 理

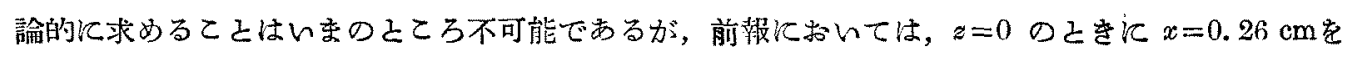
仅题して

$$
K^{1 / 2}=3.54
$$

を求めた。

前章においてのへた如く，地球上のオゾンの全量は，つ权に一定であるから，光化学的平衡量の

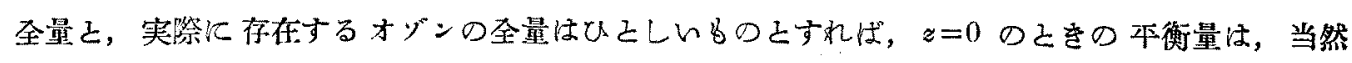
$0.26 \mathrm{~cm}$ より大となり，0.4cm 位にえらぶのが穻当である.このこえから，Kの值としては，

$$
K^{1 / 2}=4.02
$$

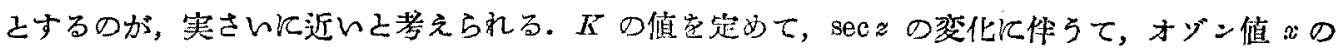

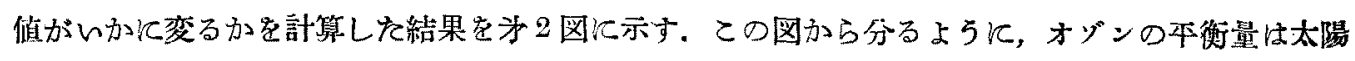

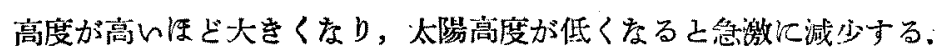

天頂距離 2 之緯度 $\varphi$, 及び特刻 $t$ 己の関係は,

$$
\cos z=\sin \varphi \cdot \sin \delta+\cos \phi \cdot \cos \delta \cdot \cos t
$$

そいう周知の式で与えられる。ことによは日赤緯である。この式から各緯度でとの每月のオゲン乎 


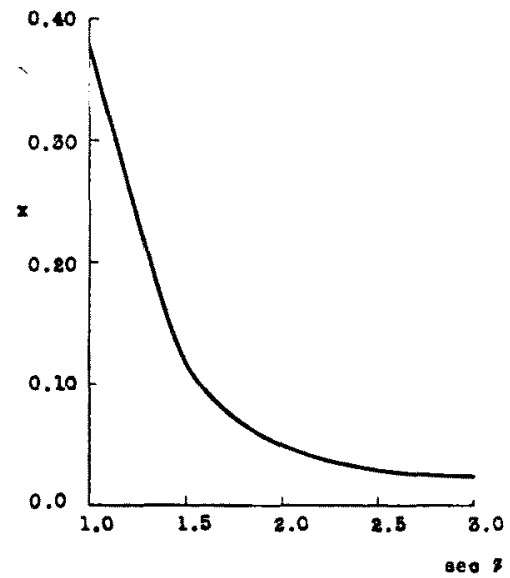

Fig. 3 Relation between $x$ and $\sec z$.

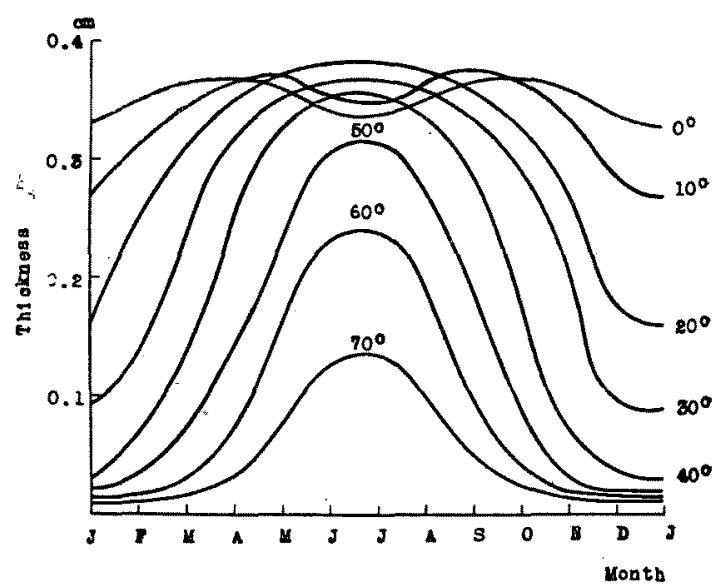

Fig. 4 Meridional variation of the photochemical formation of ozone

衡量を求めるこよができる。その結果は为 4 図に示すよ5になり，亦道では平衡量は最も大きく， 春分之秋分几極大を示す 夏至 (北牛球) 几は北回㷌線上で，冬至 (北北球) には南回僵線上で,

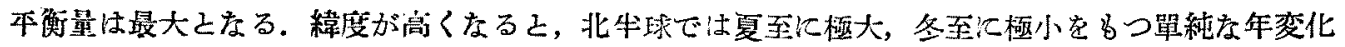

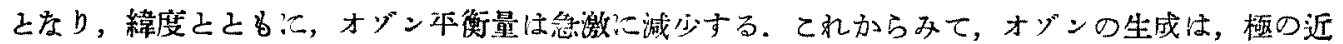
くではきかめて少ないてとがわかる。

2. 光化学本衡江あるオゾンの質量分布之総量

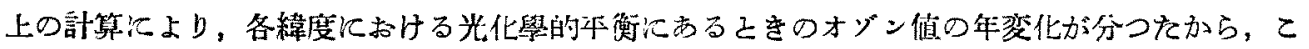

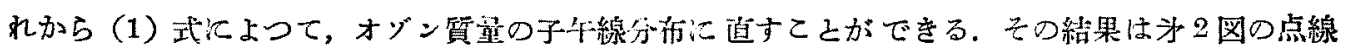
によつて示す. 図で分るよ5に, 光化学的平衡儿よるオゾン質量は, 赤道地帶で大となり, 極大は,

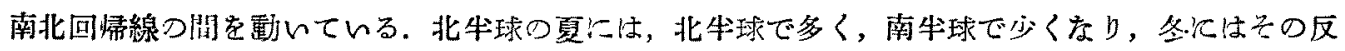

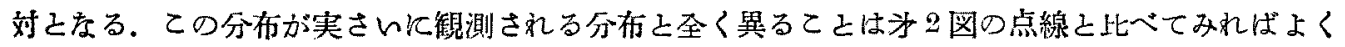
分る. 光化学平衡量の分布は山型をしているが，钼測される分布は本らな丘型である。

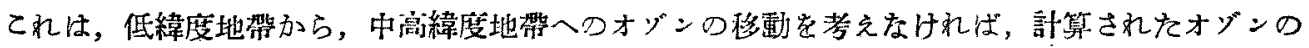
質量分布が，実際の分布にはなり得ないてと宕物語つている。

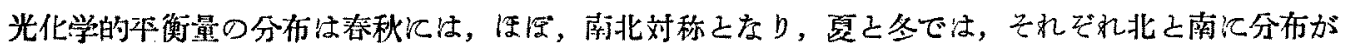
移動するが，地球上の総量に着目すれば，一年中，一定亡思われる。（2）式にしたがつて，地球上

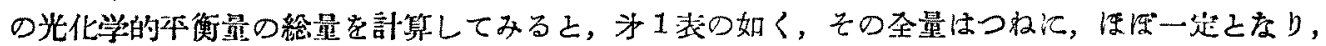
地球上で観測されるオゲンの全量とひとしいてこがかかる。実さいには，オゲンは赤外線の吸收， 遈元牲物質との接触などによつて，一部には破壊されるが，乙れらの分解作用は为一近似としては 一応艁視して考えることにする. 
以上から，つ豈の上うなてとが考えられる。

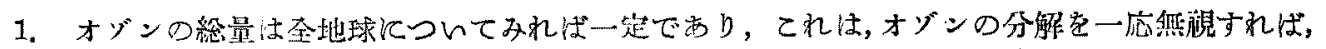

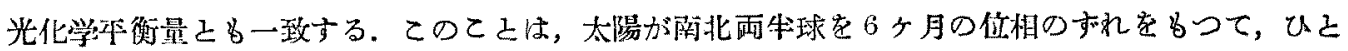
しい强さで照らしているてとから，当然予想できるここである。

2. しかし, 実さい存在するオゲンの子年線分布之, 光化学平衡量の分布とはひさしくない.

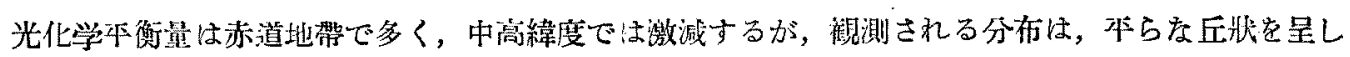

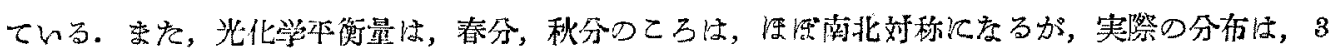

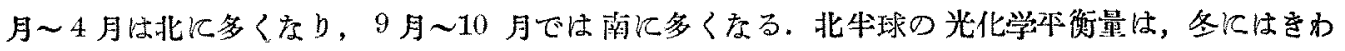

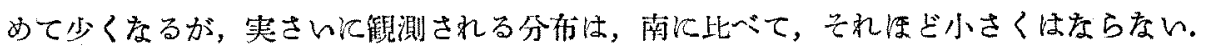

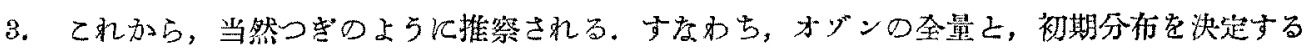
ものは，輻射强度であり，輻射の分布化対応して，光化学平衡量の分布がきる。乙の初期分布が，

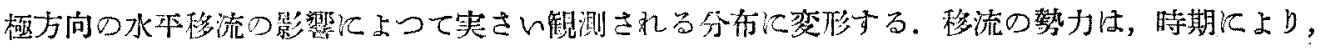

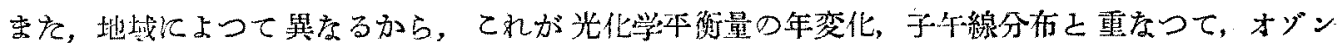

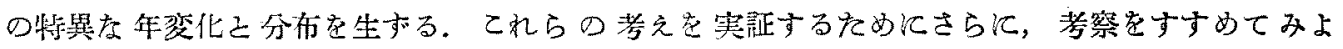
5 .

\section{第 3 章 オン゙ンの子午線方向への翰遂}

\section{1. 輸邆による說明の可能性}

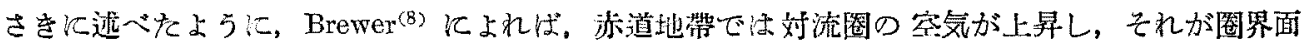

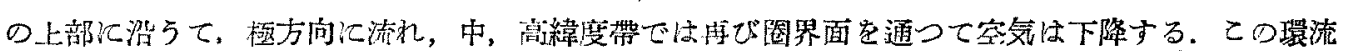

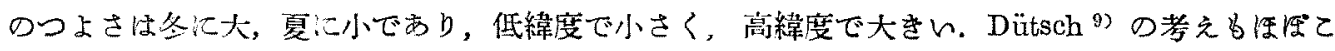

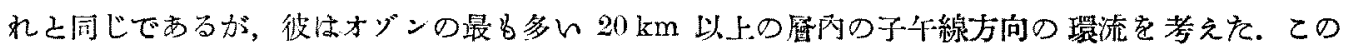

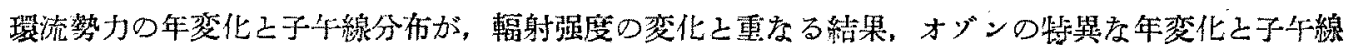
分布をもをらす之考えるてとは，合理的であろう，ここではてれらの考えを発展し，さらにいくら 少定量的行あつかつてみよ.

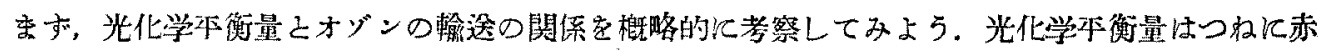
道附近で多いが，てれは移流によつて，それぞれ南北の中，高緯度方向にはてばれる，北牛球の冬

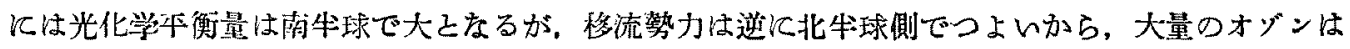

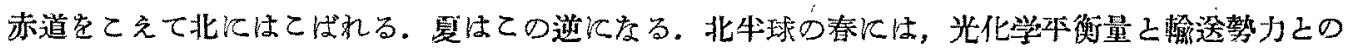
重なりで，オゾン極大定生到る條件ができる，オゾンの全量は一定であるから，当然，南牛球では オゾン極小之をる。秋はての逆.

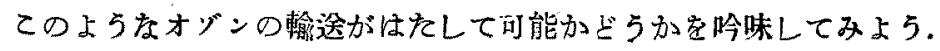




\section{2. 成篔圈內における渦動拡散保数の推算}

Brewer はヘリウムの高さによる分触率から計算して，圈界面のすぐ上の鉛直方向の渦㢦拡散係 数として，10 結諭した.

オゾンの愓合には，图界面のすぐ上防かでなく，むしろ，オゾンの多い $25 \mathrm{~km}$ な心とした 居の流れにつレて考察する必要がある. したがつて $25 \mathrm{~km}$ から $40 \mathrm{~km}$ 附近までの渦動搪散媇数 を推定してみよう。

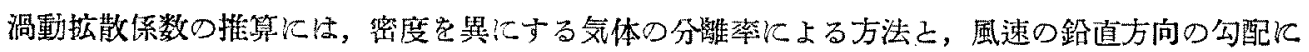
よる方法とがある。

空気と密度を異にする気体の分離については Brewer の用んてつきの式がある。

$$
\frac{\partial p^{\prime}}{\partial t}=\frac{\partial}{\partial h} D\left(\frac{\partial p^{\prime}}{\partial h}-\frac{g p^{\prime}}{R^{\prime} T}\right)+\frac{g p^{\prime}}{\partial h} k\left(\frac{\partial p^{\prime}}{\partial h}-\frac{g p^{\prime}}{R T}\right)=0
$$

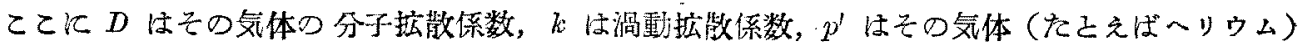
の分圧， $R^{\prime}, R$ はそれぞれ，之の気体之空気の比気体定数， $t$ は特間， $T$ は気溫， $h$ は高さであ る.この式を解いて畫正す之，

$$
\frac{\log (1+f)}{\log p_{1} / p_{2}}=\frac{D\left(R / R^{\prime}-1\right)}{D+k}
$$

こてで $f$ はその気体の分啨率，すなわち組成垐化の割合である。

一般に分子形散係数 $D$ は次式によつて，近似的にもとめるここができる。

$$
D=0.0043 \frac{T^{3 / 2}}{p\left(V_{A^{3}}+V_{E}^{1 / 3}\right)} \sqrt{\frac{1}{M_{A}}+\frac{1}{M_{B}}}
$$

こてで， $V_{A} ， V_{B}$ はそれぞれその気体之空気の分子容積に相当する量， $M_{A} ， M_{B}$ はそれぞれ，そ の気体と空気の分子量， $p$ は気殴である.

一方，風速の高さに上る傾さから分子拡散係数 $k$ を求めるには次式による.

$$
k=A / \rho=l^{2} \frac{\partial V}{\partial h} \mid h
$$

ここで, $A$ は地上からの高さ $h$ における交換係数, $\rho$ はその高さの空気密度, $l$ は艾換要素の 平均自由行路，Vは風速である。

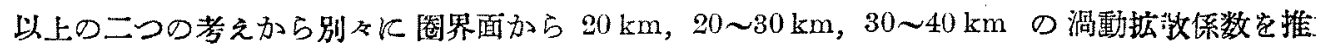
算してみよう。

a. 圈界面から $20 \mathrm{~km}$ 附近なで 
Brewer 忙 $20 \mathrm{~km}$ でへリウム*が $0.5 \%$ 多くなるとして, (15) 式によつて, $k \approx 400 \mathrm{~cm}^{2} \cdot \mathrm{sec}^{-1}$ を

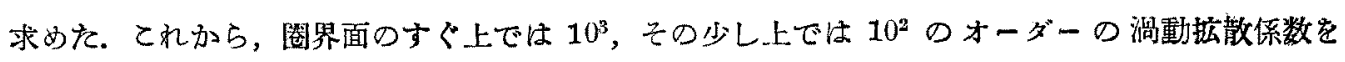
るつととが妥当であると考えた。

これさ同じ方法で，酸素の高されよる減少率の測定值を用いて，kを計算することもできる。

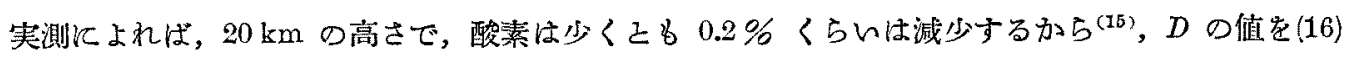
式により，10 km では $0.59,20 \mathrm{~km}$ では 2.8 として計算すると，

$$
k \approx 140
$$

を得る.乙の值はへリウムからの計算より，やゃ小さく，kの最小值を示するのであろう.

一方，風速の傾きによる計算沈よれば，Schröer ${ }^{(16)}$ は圈界面の上では $k=8 \times 10^{2} ， 20 \mathrm{~km}$ の近く では $4.9 \times 10^{2}$ を得ているから，乙れらの資料它綜合する之，图界面から $20 \mathrm{~km}$ の閒では，圈界 面の上では $10^{3}, 20 \mathrm{~km}$ の近くで $10^{2}$ という推算はお之らく真化近いものと考えられる.

b. $20 \mathrm{~km}$ から $30 \mathrm{~km}$ まで

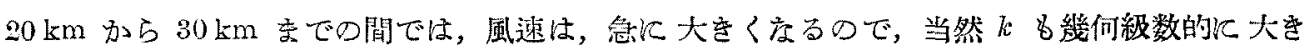
くなる，ての高さでは，気体の拡散分離のよい溉定例がないので，風速による計算值を用いる。

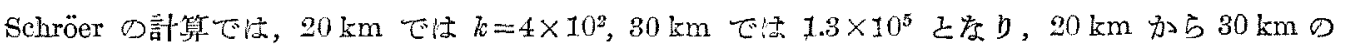
間でにの值が急激汇管すことを示している。

c. $30 \mathrm{~km}$ から $40 \mathrm{~km}$ まで

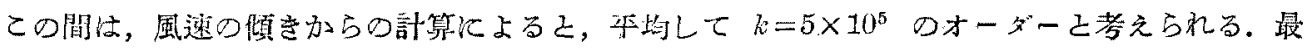

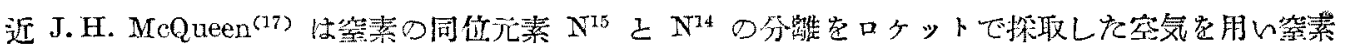

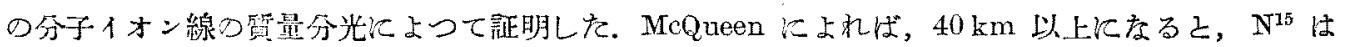

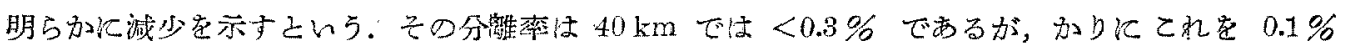

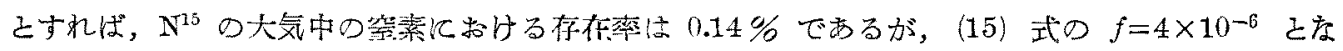

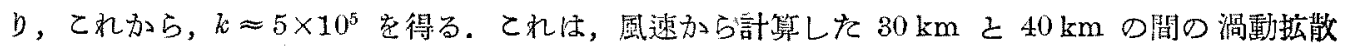

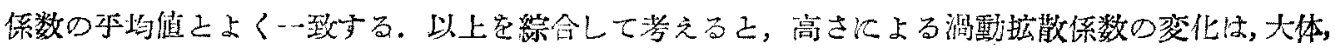
为 表の如きものとしてよレであらう。

Brewer の $k$ が $2 \times 10^{3}$ のオーダーのとをに, 極方向の移流のはやさとして, 平均して $v=0.5 \mathrm{~m}$ 位の流れが，圈界面㳊沿与て低緯度から高緯度に向つて存在するこ上が予想される上いつているが

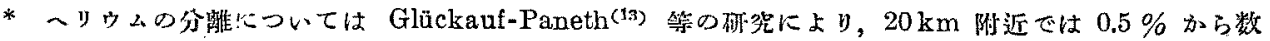

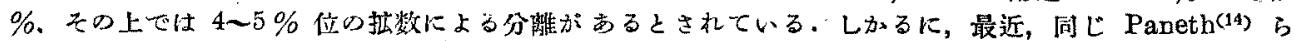

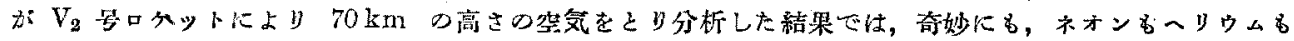
地上の組成と贸りはなく，むしろ，ーリウムの制合恃かえつて減少しているかの観を与えている。しかし， との空気資料については，地上の空気の混入の心配があるので，を゙決定的な結諭とはいえない. 
Table 2. The vertical distribution of eddy diffusion coefficient $k$

\begin{tabular}{|c|c|c|}
\hline 漓 & 瀜動 㧓散俨数 $k$ & 推算 \\
\hline 图桇面の上 & $1 \sim 2 \cdot 10^{3}$ & 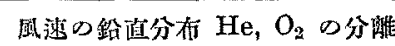 \\
\hline $20 \mathrm{~km}$ & $2 \sim 4 \cdot 10^{2}$ & 同 上一 \\
\hline $30 \mathrm{~km}$ & ca $1 \cdot 10^{5}$ & 栭逝の鉛㨁分布 \\
\hline $30 \sim 40 \mathrm{~km}$ & ca $5 \cdot 10^{5}$ & 風速の鉛㨁分右 $\mathrm{N}^{15}$ の分離 \\
\hline
\end{tabular}

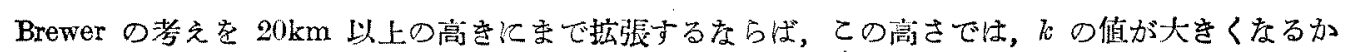

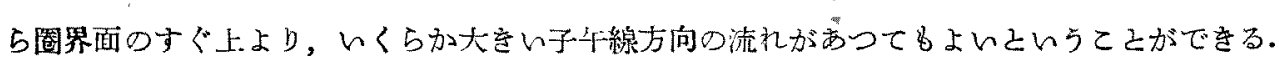

\section{3. 大気オン゙ンの子午線上における輸送速度}

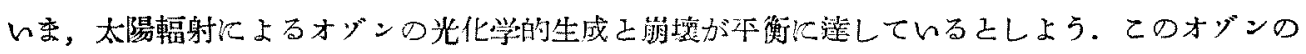

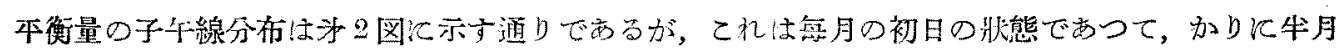

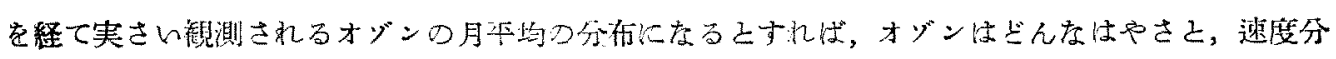
布をるつて移動したらよいかを計算してみよ5。

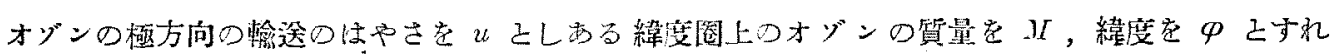

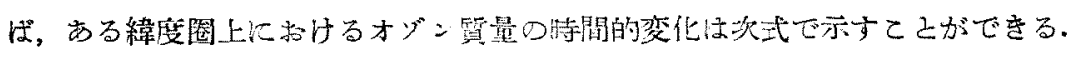

$$
\frac{d M}{d t}=\frac{\partial M}{\partial t}-n \frac{\partial u}{\partial \varphi}-v \frac{\partial M}{\partial \varphi}
$$

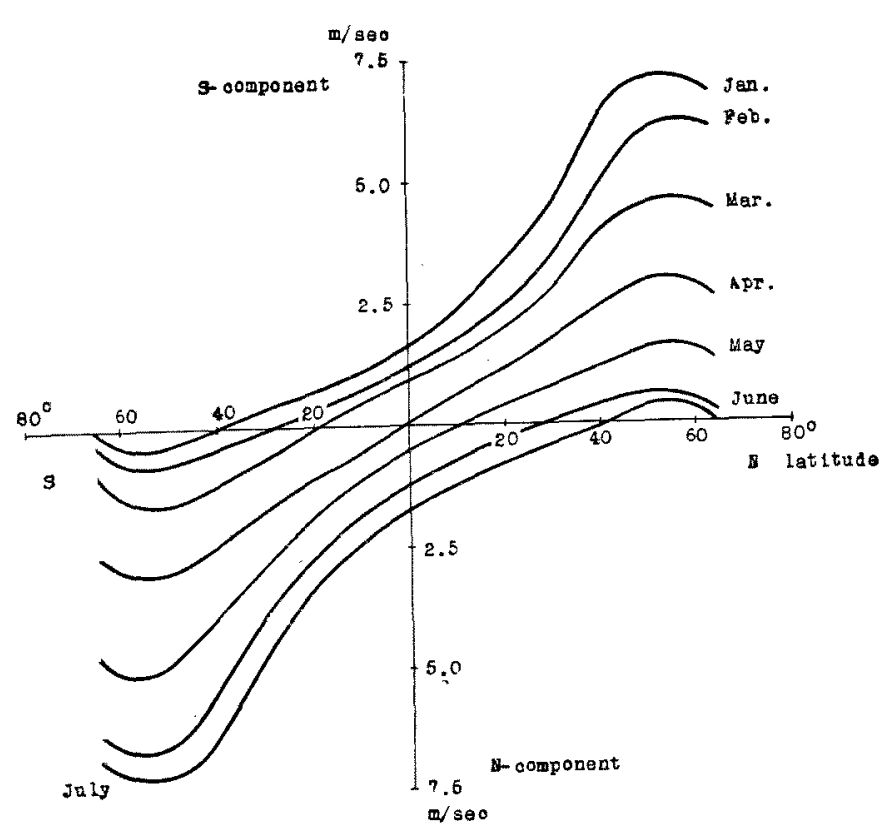

Fig 5. The velocity of meridional mass transport of ozone 


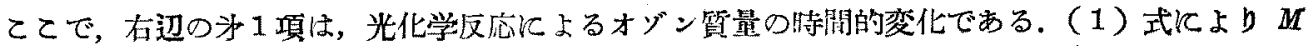
を書きかえると，上式は次のよう沉なる。

$$
\frac{d^{2} x}{d t}=\frac{\partial x}{\partial t}+u\left\{x \ln \varphi-\cos \varphi \frac{\partial x}{\partial \varphi}\right\}-x \cdot \cos \phi \frac{\partial t}{\partial \varphi}
$$

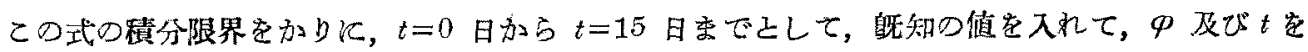

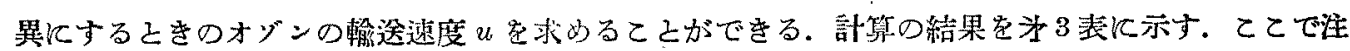

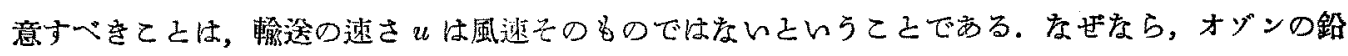

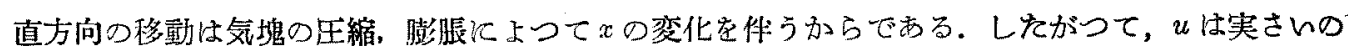
水平輸邆已鉛直流の結果が重つて生じた，見かけの子年線上の流れの速さとみなし得るるのであ 子.

Table 3. The velocity of pole-ward transport of ozone.

$(+:$ North ward) $\mathrm{m} / \mathrm{sec}$.

\begin{tabular}{r|r|r|r|r|r|r|r}
\hline Lat. & Jan & Feb & Mer & Apr & May & June & July \\
\hline N 65 & +6.8 & +6.0 & +3.8 & +1.6 & +1.5 & +0.2 & +0.03 \\
55 & +7.1 & +6.2 & +4.0 & +1.7 & +1.2 & +0.4 & +0.08 \\
45 & +6.9 & +5.8 & +4.2 & +1.7 & +1.1 & +0.4 & -0.1 \\
35 & +4.6 & +4.2 & +3.2 & +1.5 & +0.9 & +0.2 & -0.2 \\
25 & +3.8 & +2.8 & +2.2 & +1.2 & +0.6 & -0.3 & -0.5 \\
05 & +2.7 & +2.0 & +1.6 & +0.8 & +0.2 & -0.7 & -0.9 \\
$\mathrm{~N} 5$ & +1.8 & +1.4 & +1.2 & +0.4 & -0.4 & -1.0 & -1.4 \\
$\mathrm{~S} 5$ & +1.4 & +1.0 & +0.8 & -0.4 & -0.8 & -1.5 & -1.8 \\
15 & +0.9 & +0.8 & +0.3 & -0.8 & -.13 & -2.3 & -2.7 \\
25 & +0.5 & +0.5 & -0.25 & -1.1 & -1.8 & -3.2 & -3.8 \\
35 & +0.2 & -0.3 & -0.4 & -1.4 & -2.4 & -4.6 & -4.6 \\
45 & -0.1 & -0.1 & -0.6 & -1.8 & -3.3 & -6.1 & -6.9 \\
55 & -0.08 & 0 & -0.6 & -2.0 & -3.0 & -6.6 & -7.1 \\
65 & -0.03 & 0 & -0.3 & -0.8 & -2.5 & -62 & 16.8 \\
$50 \hat{4}$ & 2.9 & 2.2 & 1.8 & 1.2 & 1.5 & 2.4 & 2.9 \\
\hline
\end{tabular}

上の表で分る上5K，北牛球の冬では，南緯 $40^{\circ}$ 附近から北牛球に向つて，オゾンが輸途され，

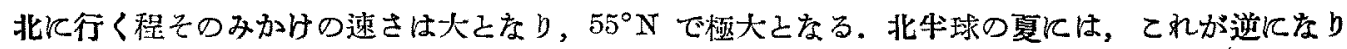

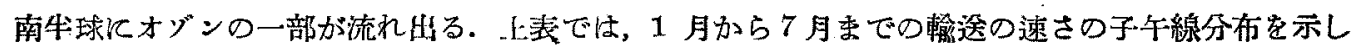
たが，それ以降は牛年前の值を南北逆汇しをるのとなる。これらの見かけの速さは，風速之のもの

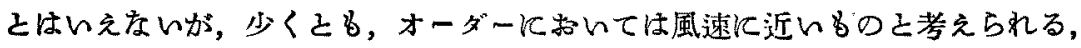

オン゙ンの見かけの輸送速度の絕対値の平均は, 全地球上では 1 月之 7 月に $2.9 \mathrm{~m} / \mathrm{sec}, 4$ 月之 10

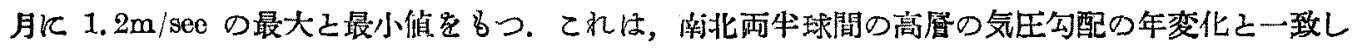


ている. Brewer は圈界面の.上で, 佩動昖散率 $k=2.10^{3}$ Łして $0.5 \mathrm{~m} / \mathrm{sec}$ の平均水平流（極方向）

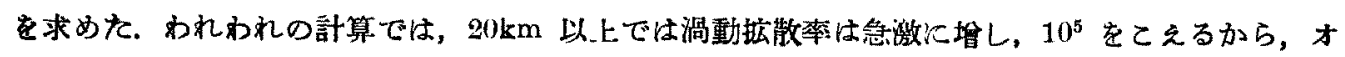

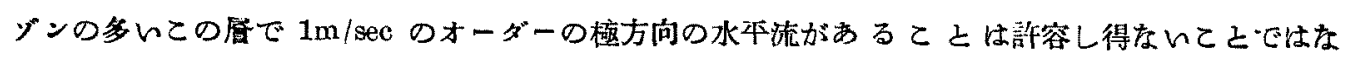

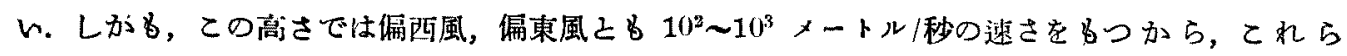
が 1〜10メートル/秒の南北成分をるつとともあり得ないてさではない.

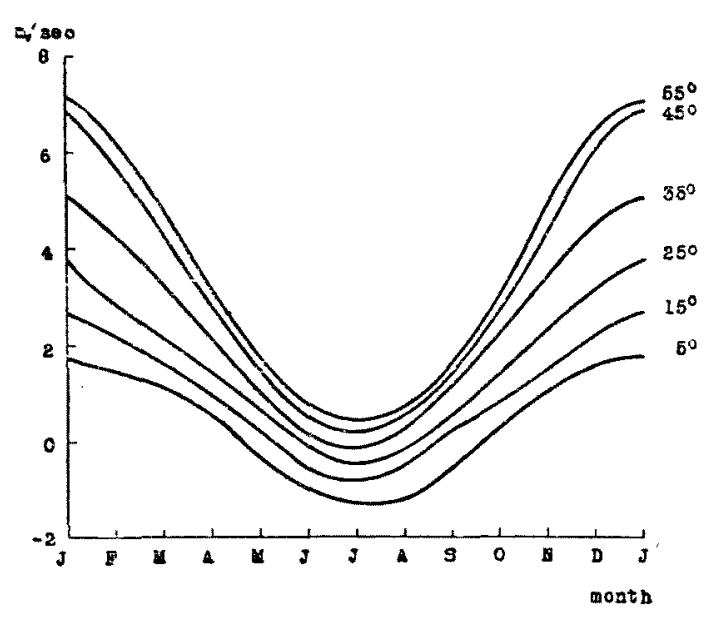

Fig 6. Annual variation of transport velocity of ozone

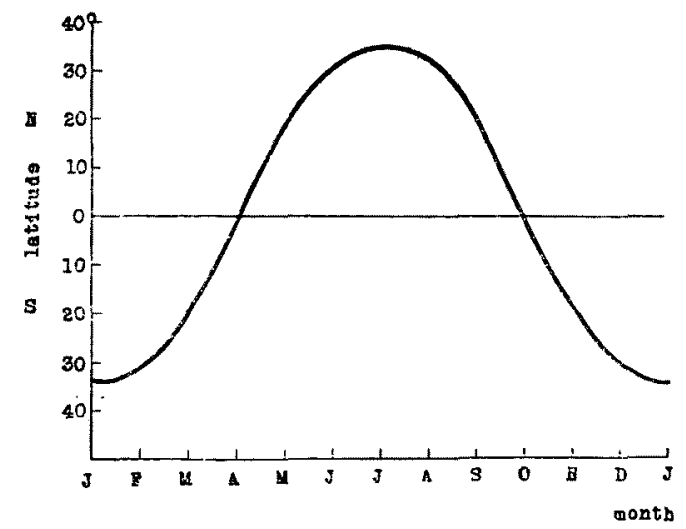

Fig 7. Annual variation of reversing point in transport direction

同一の緯度におりる榆迼速度の年变化をみる 之为6图の如く，冬水大，夏机小（低緯度で は夏江は輸途速度は頁儿なる）上なり，てれ 6大気の覆乱度からみて当然の年变化であ る、また，同一特期では，緯度它すすほ速 度が大きくなるこ己常識化一致する。

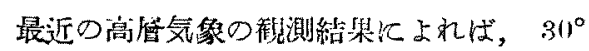
Nから $40^{\circ} \mathrm{N}$ 附近では $18 \mathrm{~km}$ 以上は，冬沉 はっ上い西風, 夏化は少し上わく熶大 5 $\mathrm{m} / \mathrm{sec}$ くらんの偏東風であることがたしかめ られた。風の交替期は 5 月はじめでらと 9 月

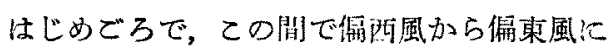
なる.てのて之は, 冬は空気の北上，夏は率 下寸ることを示し，われわれがオブンの輸䢒 から得を結諭を支持する，オゲン錸运つ場合 には，輸送方向の突替期は $30^{\circ} \mathbb{N}$ では 6 月己 8月であつて, 風の卒替期上り間隔が獭いが，

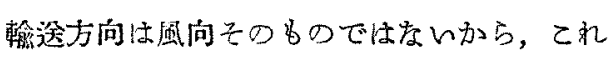
はさしろょい一致之みるべきである。（为7 図)

\section{むすび}

大気オゾンの年変化之子午線分布之は，オゾ ンの全量が地球上.ではつね机一这であること

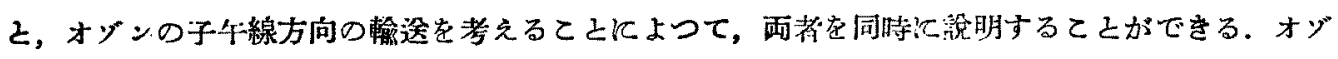

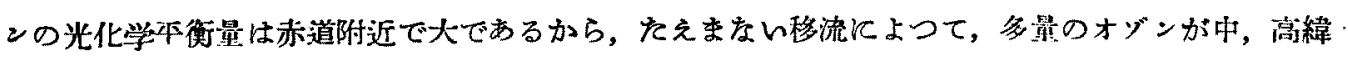

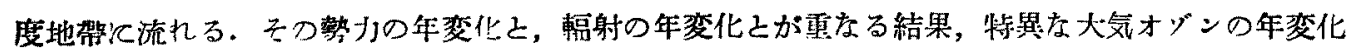




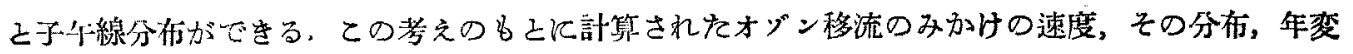

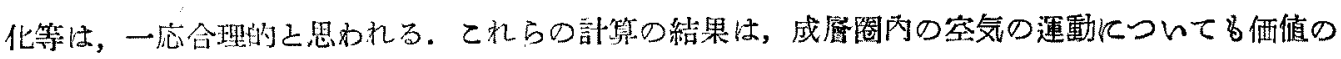
ある示䛋昰包含するbの之思う。

\section{References}

(1) Y. Miyake and K. Saruhashi: Geophys. Mag., 21 (1950), 99.

(2) Chapman: Phil. Mag. 10 (1930), 345.

(3) R. Penndorf: Veröff. Geophys. Inst. Leipzig 8 (1936), 181, Naturwiss. 25 (1937). 774., Annal. de Geophys. 6 (1950), 1.

(4) M. Nicolet: Inst. Roy. Met. de Belgique Mis. Fasc. XIX (1944).

(5) A. Vassy et E. Vassy: J. de Phys. VIII 2 (1941), 81.

(6) H. U. Dũtsch: Arch. Met. Geopbys. u. Bioklima, Serie A, Bd. 2, Heft 4 (1950), 386.

(7) G. M. B. Dobson, D. N. Harrison and J. Lawrence: Proc. Roy. Soc. Londn A. 122 (1929) 484.

(8) A. W. Brewer: Quart. Jour. Roy. Met. Soc., 75 (1949), 351.

(9) H. U. Dütsch:Inaugural Dissertation, Univ. Zürich, 1946, Zürich.

(10) M. Moser: Ber. deutsebe Wetterd. in U. S. Zone, Nr. 11, 1919.

(11) R. J. Reel: Jour. Met. 7 (1950), 263.

(12) R. Mecke:Trans. Faraday Soc. 1931, The Photochemical processes, a general discussion.

(13) E. Glückauf and F. A. Paneth: Nature 138 (1936), 544. 139 (1987), 180, 220.

(14) K. F. Chackett, F. A. Paneth and E. J. Wilson: Nature, 164 (1949), 128.

(15) Regener: Nature, 138 (1936), 544.

Lepape et Colange: Compt. rend, 900 (1835), 1872.

Nat. Geogr. Soc, and U. S. Army Air Corps: "Stratosphere Flight of 1935 in the Balloon "Explorer II" ", Washington, (1936).

(16) E. Schräer: Ber. deut. Wetterd. in U. S. Zone, Nr. II (1949), 13.

(17) J. H. McQueen: Nature 166 (1950), 100. Phys. Rev: 80 (1950), 100.

(13) C. J. Brasefield: Jour. Met. 7 (1950), 66.

B. Gutenberg: Bull. Am. Met. Soc. 30 (1949), 62. 